\title{
Styrning genom samverkan? - En textanalys av dominerande diskurser i en statlig skolförbättringssatsning
}

\author{
Malin Kron qvis t $\mathrm{H}$ å åd \\ Högskolan Dalarna
}

\begin{abstract}
Artikeln tar sin utgångspunkt i tre texter rörande skolförbättringssatsningen Samverkan för bästa skola (SBS) varav två kan betecknas som policytexter och den tredje är en myndighets hemsida rörande SBS. Policydiskurser är viktiga att undersöka i och med att de ramar in vad som är den politiska viljan kring ett givet fenomen. Genom policy konstrueras mening och identifieras problem i utbildning. Syftet med studien är att skriva fram ett tänkbart narrativ om SBS för att synliggöra och lyfta fram underliggande diskurser i retoriken kring SBS i de analyserade texterna. Analysen har guidats av både en narrativ och en diskursiv ansats. Ett styrningsperspektiv har anlagts i analysen med utgångspunkt i governance och governmentality. I analysen lyfts olika konkurrerande diskurser fram spänningen mellan samverkan och styrning, mellan decentralisering och kontroll. Studiens kunskapsbidrag är att den kritiskt granskar en av de största skolutvecklingssatsningar som gjorts i svensk skola och ett resonemang om de underliggande antaganden som identifierats i analysen förs. Att vara kritisk betyder inte att säga hur saker egentligen är, utan vad diskursanalyser av detta slag kan bidra med är att lyfta blicken från dessa underliggande common sense-antaganden som genomsyrar offentliga texter och på så sätt öppna upp för alternativa tankesätt och handlingssätt.
\end{abstract}

\section{INLEDNING}

I det svenska utbildningssystemet pågår en rad skolförbättringssatsningar. ${ }^{1}$ Skolutveckling tycks självklart och behjärtansvärt. Den förväntas få konsekvenser för hur kommuner, huvudmän och skolor organiserar sin utbildning samt utformar undervisningen i klassrummen (Holmdahl, 2011). De senaste tre decennierna har det svenska skolsystemet präglats av många 
reformer och omstruktureringar vilka till stor del följt en internationell trend där neoliberal ideologi och New Public Management (NPM) varit i centrum (Lundström, 2018). Själva namnet på den skolförbättringssatsning som är i fokus för detta temanummer - Samverkan för bästa skola (SBS) - för tankarna till den nämnda ideologin som många pekat på spridit sig världen över (Börjesson, 2016; Olssen \& Peters, 2005; Popkewitz \& Lindblad, 2000). Genom samverkan, som kan ses som ett politiskt modeord (Dahlstedt \& Hertzberg, 2011), ska Sverige få den bästa skolan i en tid som präglas av konkurrens om att vara en ledande kunskapsnation (Säfström, 2005). En dominerande ideologi bestämmer i hög utsträckning vad som ska uppfattas som "common sense" i samhället (Börjesson, 2016, s. 57; Fairclough, 2001; Springer, 2012). Vad som sedan blir uppfattat som common sense förlorar sin ideologiska prägel, det blir så att säga neutralt och den gängse uppfattningen man bör ha (Fairclough, 2001). Den här artikeln analyserar tre offentliga texter rörande SBS. Orden som används i texterna har betydelse eftersom de konstituerar det vi pratar om, hur skola görs och vad politiker i förlängningen väljer att satsa skattemedel på. Statliga texter konstituerar den dominerande utbildningsideologin i samhället (Börjesson, 2016) och vad skola blir (jfr Ball 2015). Diskurser i offentliga texter är viktiga att undersöka i och med att de ramar in vad som är den politiska viljan kring ett givet fenomen. Genom policy och offentliga texter konstrueras mening och identifieras problem i utbildning. Policy och offentliga texter sätter också ramar för det som är sägbart, görbart och tänkbart (Ball, 1993, 2006; Bacchi, 2000; Foucault, 1980). De offentliga texterna ses i detta sammanhang alltså som diskurs och inte bara text (se Ball, 1993).

Studiens kunskapsbidrag är att den kritiskt granskar en av de största skolutvecklingssatsningarna som gjorts i svensk skola genom att belysa och diskutera några av de diskurser som framträder i ett begränsats antal policytexter; nämligen regeringsbeslutet (Utbildningsdepartementet, 2015), Skolverkets genomförandeplan (Skolverket, 2016) och Skolverkets hemsida rörande SBS (Skolverket, 2019b). Offentliga texter och policy behöver kritiskt belysas för att kunna peka på underliggande antaganden och på så sätt också öppna upp för alternativa tankesätt, kring skolutveckling och styrning i detta fall. Popkewitz och Lindblad (2000) menar att policyforskning inom utbildning tenderar att acceptera de diskurser som beslutsfattare definierar "taking the categories and problem definitions derived from governmental policies as the problems of research without any serious intellectual scrutiny" (s. 6). I artikeln görs en narrativ diskursanalys med speciellt fokus på vad styrning, samverkan och skolutveckling innebär i SBS. Syftet med studien är att skriva fram ett tänkbart narrativ om SBS för att synliggöra och lyfta fram underliggande diskurser i retoriken kring SBS i de analyserade texterna. Då artikeln hämtar inspiration från Foucault är det viktigt att poängtera att flera möjliga läsningar av en text alltid finns, men jag presenterar en läsning utifrån 
ett teoretiskt raster där begreppen governmentality, styrning och samverkan är centrala. Tre frågor har guidat artikeln. Den första är en övergripande fråga - vad är storyn om SBS i dessa texter och hur är den berättad? Två mer specifika frågor följer: vilka diskurser går att utläsa i den identifierade storyn och vilka subjektspositioner kan urskönjas i denna?

\section{BAKGRUND}

Svensk skola har sedan 1990-talet genomgått ett systemskifte (Carlbaum et al., 2014), från regel- och resursstyrning till mål- och resultatstyrning, från statligt styrd skola till ett av de mest decentraliserade och marknadsliberala skolsystemen i världen (Börjesson, 2016; Carlbaum et al., 2014; Lundahl, 2007). Till detta kom på 2000-talet "PISA-chocken", rapporter om sjunkande elevresultat och ett allt större fokus på måluppfyllelse, likvärdighet och kvalitet (Bergh, 2015). I ljuset av PISA-chock och sjunkande elevresultat har det också pågått en debatt om återförstatligande av skolan (SOU 2014:5). Flera åtgärder de senaste åren (fler nationella prov, betyg i yngre åldrar och inspektioner) kan ses som en form av recentralisering där staten har tagit ett fastare grepp om skolan (Lundström, 2018; Nordin, 2014a, 2014b). Den statliga skolförbättringssatsningen SBS kan ses som ett av statens svar på de sjunkande skolresultaten och den skola i kris som skrivits fram i media med stöd i bland annat internationella mätningar (Nordin, 2014a; OECD, 2015). Samverkan för bästa skolor riktar sig mot skolor "med låga kunskapsresultat eller hög andel elever som inte fullföljer sina studier och som har eller bedöms få svåra förutsättningar att förbättra sina resultat på egen hand" (Utbildningsdepartementet, 2015, s. 1). De skolor och huvudmän som erbjuds att delta i SBS väljs ut på grundval av Skolinspektionens regelbundna tillsyn vilket kan betecknas som ett negativt urval. ${ }^{2}$ När huvudmännen accepterat erbjudandet att delta påbörjas en cirka sex månader lång dialog- och kartläggningsfas där överenskommelser mellan parterna skrivs och en åtgärdsplan för insatserna skrivs. Insatserna pågår sedan under cirka två år där olika aktörer kan vara inblandade, lärosäten, konsulter och Skolverket. I regeringsbeslutet (Utbildningsdepartementet, 2015) åberopas skollagens (2010:800) skrivelser om barns och elevers lika tillgång till utbildning och en likvärdig utbildning som skäl till beslutet att starta SBS.

Den utbildningspolitiska diskursen som nu råder är starkt influerad av NPM-retorik där ord som effektivitet, flexibilitet och ekonomiska resultat är vanligt förekommande (Olssen \& Peters, 2005). Grek (2009) kallar det för "governing by numbers". Gällande skolutvecklingsreformer lyfter Røvik och Pettersen (2014) fram fyra typiska idéer i vår tid: kvalitet, ledning, accountability och evidensbaserad praktik. Dessa idéer hämtar sin spridningskraft från social auktorisering, det vill säga att idéer associeras positivt till olika aktörer, nätverk och institutioner som har högt anseende och auktoritet och 
därmed ger legitimitet till idéerna. Sett till kompetensutvecklingsinsatser i skolan så implementeras dessa ofta ur ett ovanifrånperspektiv både i Sverige och internationellt (Fink \& Stoll, 2005; Sülau, 2019). Ofta utgår denna traditionella fortbildning utifrån ett bristperspektiv där det handlar om att överföra de "rätta" kunskaperna där mottagaren av utbildningen passivt tar emot kunskap som överförs av experter eller forskning (Clarke \& Hollingsworth, 2002; Day \& Sachs, 2004; Sülau, 2019). Skolverket har som ett av sina uppdrag att erbjuda kompetensutveckling till skolor och kommuner. Skolverkets roll, som statlig myndighet, har ökat i betydelse och Skolverkets roll i att sprida och ge legitimitet till idéer genom till exempel skolutvecklingsprogram är hög (Ärlestig \& Johansson, 2020).

\section{Statlig styrning och samverkan}

Den statliga styrningen har genomgått flera förändringar de senaste årtiondena. Osborne (2010) delar in förändringar inom statlig styrning $i$ "Public Administration" (PA) som även kan betecknas som traditionell topdown-styrning via lagar, subventioner och information, "New Public Management" (NPM), som tidigare diskuterats, handlar bland annat om decentralisering, prestationsstyrning och prestationsmätning samt"New Public Governance" (NPG) för att beskriva trenden för mer horisontell styrning via nätverk och relationer. Interaktioner mellan aktörer är i fokus och systemet bygger på att det finns utrymme för autonomi för aktörerna $i$ nätverken (se även Montin \& Hedlund, 2009; Magnusson, 2018; Ärlestig \& Johansson, 2020, för en diskussion om dessa begrepp; jfr Olsson et al., 2019). Styrning via nätverk är ett sätt för staten att stärka sin legitimitet och effektivitet genom att involvera lokala aktörer i implementering (Pollitt \& Bouckaert, 2011). Dessa tre förändringar inom styrsätt ska inte ses som absoluta, utan som Montin och Hedlund (2009) påpekar är gränserna mellan dem flytande och alla tre kan förekomma samtidigt i olika sammanhang. I fallet SBS kan nätverksmodellen antas vara viktig då namnet på själva insatsen innehåller ordet samverkan.

Som nämndes tidigare är det många parter som ska samverka i SBS: Skolverket, huvudmän, skolor och lärosäten för att nämna några. Ordet samverkan har beskrivits som ett "politiskt modeord" och ett "utbildningspolitiskt ideal" (Dahlstedt \& Hertzberg, 2011, s. 149f). Enligt Pollitt och Hupe (2011) är det ett begrepp som har "retoriska fördelar" med "bred räckvidd, stor flexibilitet och positiva förtecken" (s. 642). Det finns inte en definition av samverkan utan många. Sullivan och Skelcher (2002, s. 1) beskriver samverkan som: "a way of working with others where there is a shared interest in positive outcomes". Lindberg (2009) skriver att ordet samverkan ofta ses i ett positivt skimmer och att det ofta råder en optimistisk stämning kring ordet samverkan även inom forskning. Normativa råd om hur fördelarna med samverkan ska uppnås är vanligt förekommande. Att 
samverka inom offentlig förvaltning är inte något nytt, men förändrade styrsätt från centralisering till decentralisering ger nya spelregler (Bengtsson \& Melke, 2019; Danermark \& Kullberg, 1999). Samverkan är inte längre bara ett alternativt arbetssätt utan beskrivs av Danermark och Kullberg (1999, s. 9) som "en nödvändig arbetsform". Dahlstedt och Hertzberg (2011) menar dock att mer kritiska reflektioner kring samverkan behövs, bland annat i frågan om begreppets neutrala prägel där samverkan ofta beskrivs som "en relation mellan jämlikar" (Dahlstedt \& Hertzberg, 2011, s. 9). Samverkan kan vara en relation mellan jämlikar, menar Dahlstedt och Hertzberg, men det kan också vara frågan om en relation mellan överordnad och underordnad. Även Danermark (2004) uppmanar till mer kritisk reflektion kring begreppet samverkan och manar till fler studier om makt i relation till samverkan.

Begreppet samverkan kan också ses som en del av rörelsen från government till governance, som diskuterats ovan. Från styrning via hierarki till styrning via marknad och nätverk (Olsson et al., 2019), där en diskurs om samverkan, nätverk, partnerskap, samarbete och tillit, för att nämna några begrepp, har etablerats (Cardini, 2006; Watson \& Drew, 2017). Termen governance kan ge sken av att statens roll i utbildningsfrågor har minskat, men staten har hittat andra sätt att styra skola på (jfr Bradbury et al., 2013). Nya former av styrning, så kallad "soft governance", som benchmarking eller best practice kan till och med stärka statens makt över skolan. (se t.ex. Hudson, 2007; Moos, 2009; jfr Pierre \& Peters, 2000). I linje med mjukare former av governance kan självutvärderingar inberäknas. Självutvärderingar skulle kunna ses som ett effektivt sätt som har till syfte att få skolor och huvudmän att anpassa sig efter vad staten anser vara "bästa skola". Detta kan ske mer direkt genom att staten tillhandahåller riktlinjer eller modeller för utvärdering eller mer indirekt genom utbildningar, material och information (Hudson, 2007; Kirsten \& Wermke, 2017). Cribb och Gewirtz (2007) menar även att kontroll kan utövas genom autonomi vilket ligger i linje med Hudsons resonemang (2007, s. 276): "a smart move on the part of the state as it effectively gets schools to regulate themselves in the way it wants". För att uttrycka det med andra ord, de med makt internaliserar förväntat beteende och lär ut "rätt" beteende genom en dominerande policydiskurs. Detta sätt att se på styrning ligger nära Foucaults (2008) begrepp governmentality (styrningsmentalitet). Governmentality handlar om att kollektiva maktprocesser styr tankar och beteende i vissa bestämda riktningar, riktningar som vanligtvis inte ifrågasätts (Foucault, 2008). Styrningen sker på avstånd och innefattar också människors vilja att aktivt styra sig själva. "Denna vilja till självreglering gör att vi själva bidrar till att bli de subjekt, exempelvis reflekterande och ansvarstagande samhällsmedborgare som vi förväntas bli” (Vallberg Roth, 2014, s. 409; jfr Hudson, 2007). Skolutveckling kan ses som en styrningsteknik där ett normaliserande av vad som just nu ses som korrekt eller best practice visas. 


\section{Diskursbegreppet}

Det finns många definitioner av ordet diskurs. Foucaults (1972, s. 49) definition används $i$ artikeln där diskurser beskrivs som: "practices that systematically form the objects of which they speak". Ball (2015, s. 307) skriver vidare att diskurser ger oss sätt att tänka och prata om våra institutionella jag (dvs. såsom vi tänker kring oss själva som en bra eller effektiv lärare till exempel), med oss själva och med andra. Vad den dominerande diskursen gör är att den ger oss ord och verktyg att tänka och prata om oss själva och den verksamhet vi verkar i på ett visst sätt som till exempel "effektiv". Även om fokus i denna artikel ligger på svenska statliga myndighetstexter ska begreppet makt inte ses som att det är uteslutande något som agenter överst i hierarkin utövar, utan makt är utbredd i olika sociala praktiker (Winther Jørgensen \& Philips, 2000). Makt är också tätt förbunden med kunskap och dessa båda förutsätter varandra. Begreppet makt är både undertryckande och nödvändig och positiv i Foucaults mening. Den gör vår värld begränsad och möjlig att orientera sig i och leva i, men makt i Foucaults mening innebär också att undersöka det som utesluts genom den maktordning som nu råder (Winther Jørgensen \& Philips, 2000). "We do not speak a discourse, it speaks us. We are subjectivities, the voices, the knowledge, the power relations that a discourse constructs and allows" (Ball, 1993, s. 14, fet stil i originalet). Kunskap och makt hänger alltså tätt samman och den förstnämnda bidrar också till att skapa subjektspositioner som bestämmer vilket utrymme för handlingsfrihet som subjekten har (Bergström et al., 2017). En vanlig kritik som lyfts fram mot Foucaultinspirerade diskursanalyser är att de är relativistiska. Foucault talar om perspektivism. Ett styrningsperspektiv används i artikeln, men det utesluter inte andra möjliga analysperspektiv eller att det analysperspektiv som används skulle vara sannare eller falskare än ett annat perspektiv. I Foucaults anda handlar det alltså inte om sant eller falskt utan om perspektiv (jfr Alvesson, 2002).

Genom att identifiera språkmönster, kan en diskursanalys visa hur de konstituerar aspekter av samhället och utröna hur och varför det språk som används sätter gränser för vad som är (och inte är) möjligt att tänka, säga och göra (jfr Ball, 1993). Analytiska tillvägagångssätt kan "dekonstruera" eller upptäcka förgivettaganden, förstå vad dessa antaganden kan betyda för individer, institutioner och det större samhället och utforska möjliga alternativ till accepterade sätt att göra saker (Shaw \& Bailey, 2009). Sammanfattningsvis så utgår artikeln från ett diskursivt perspektiv på policy och offentliga texter med Foucauldianska förtecken (Ball, 1993; Graham, 2005). Det handlar inte om huruvida samverkan och skolutveckling är bra eller dåligt, utan om hur sanningar, kunskap och subjekt formas genom diskurser. Offentliga texter ses också som ett berättande där någon form av övertalning om "det rätta" beteendet lärs ut. Vad är storyn om SBS? 


\section{MATERIAL OCH METOD}

I artikeln görs en narrativ diskursanalys av tre statliga texter rörande SBS. Det finns ingen strikt metod att följa i en diskursanalys som tar avstamp i Foucault, utan metodologiskt hämtar artikeln guidning från narrativ metod. I artikeln kombineras således "vad" och "hur", narrativ och diskurs, som Lindberg (2017) skriver, innan det finns något att kritiskt granska behöver en deskriptiv analys göras. Begreppet narrativ ska i det här sammanhanget tolkas som 'histoire' eller story (Robertson, 2017) och begreppet diskurs såsom tidigare definierats $i$ enlighet med Foucaults tankar. Både narrativ analys och diskursanalys har en social-konstruktivistisk utgångspunkt som binder dem samman (Alvesson \& Sköldberg, 2008; Börjesson, 2003). Vi förstår storyn genom att förstå vad diskursen bakom handlar om. I diskursanalyser undersöks hur den skrivna texten är influerad av sociala och kulturella normer. Diskurser formar språket som används i narrativet (Paltridge, 2012).

I artikeln analyseras två officiella texter rörande SBS: regeringens beslut (Utbildningsdepartementet, 2015) och Skolverkets genomförandeplan (Skolverket, 2016) samt Skolverkets hemsida rörande SBS. De två första texterna är valda utifrån att de utgör grunden för SBS-initiativet, varför det startas och Skolverkets tolkning av hur uppdraget ska genomföras i praktiken. Den tredje texten, Skolverkets hemsida, representerar en aktuell och mer publik bild av myndighetens officiella retorik kring SBS-initiativet. De två första texterna kan betraktas som policytexter då den första är ett regeringsbeslut och den andra texten kan kopplas till genomförandeprocessen av regeringsbeslutet. Hemsidan är inte en policytext i strikt mening, men artikeln följer Balls (1993, s. 14) definition av policy, som ligger i linje med tidigare angivna definiton av diskurs. Policy ses som officiella uttalanden av, $\mathrm{i}$ det här fallet, statliga aktörer som genom dessa uttalanden utövar makt genom "a production of 'truth' and 'knowledge', as discourse" (se även Ball, 2015). Policy ses alltså i en vid bemärkelse, som avsiktsförklaringar och riktgivningar givna av regering, riksdag eller myndighetsorganisationer. Policy har i det hänseendet för avsikt att påverka människors förståelse av ett visst fenomen. Genom att artikeln följer Foucaults definition av diskurs "practices that systematically form the objects of which they speak" (1972, s. 49) vill jag argumentera för att policy i föreliggande studie ska tolkas brett. Frågan artikeln vill belysa är vad den officiella storyn om SBS kan sägas vara och den kan då läsas in i både regeringsbeslutet, Skolverkets genomförandeplan och Skolverkets hemsida.

Regeringsbeslutet kom 2015-06-04 (Utbildningsdepartementet, 2015) och är fem sidor långt. I korthet beskriver regeringsbeslutet på cirka en halv sida genomförande av SBS, och ekonomiska ramar och redovisning av uppdraget beskrivs på en och en halv sida. Skälen till beslutet upptar sedan resterande delen av texten. Skolverkets genomförandeplan (2016) är ett längre text på 39 sidor som beskriver hur Skolverket ämnar genomföra regeringens beslut. 
Planen beskriver hur beslutet om SBS kom till, hur SBS ska genomföras och följas upp och vilka ekonomiska ramar som finns för uppdraget. Skolverkets hemsida för SBS blir vid utskrift 14 sidor. $^{3}$ De tre texterna har olika målgrupper då regeringsbeslutet är ett uppdrag riktat till Skolverket, Skolverkets genomförandeplan är ett svar till regeringen om hur uppdraget ska genomföras samt en text som ingående huvudmän och skolor kan läsa, och Skolverkets hemsida ger en mer publik bild av satsningen. Tanken är att dessa tre texter tillsammans kan bidra till att ge en ge en gemensam bild av storyn om SBS utifrån det analysraster som används i artikeln. Att begränsa antalet texter som analyserats till dessa tre har möjliggjort en mer fördjupad beskrivning av storyn än vad som är görbart om det empiriska materialet är för omfattande samtidigt som det också inneburit en begräsning av vad som blir möjligt att få syn på. En av texterna, Skolverkets genomförandeplan, har också fått särskilt stort utrymme i studien på grund av sitt omfång och mer detaljerade beskrivning.

Inom narrativ analys finns det olika metoder för att tolka text, men enligt Riessman (2005) så binds de samman av en berättande form. En narrativ analys bidrar till förståelsen av regeringsbeslut och andra officiella statliga texter genom att de har en berättelseform: "They are all tales of unsatisfactory past and better futures. The future will be better because the government is going to intervene in some way, wielding new techniques or ideas" (Pollitt, 2013, s. 901). Den narrativa analysen kan bli ett användbart redskap för att få läsaren att se bortom ytan av texten; hur är berättelsen om SBS konstruerad och vad vill den säga om hur skolan har varit och vad den i framtiden ska bli genom samverkan? I en kritisk läsning av texterna blir också frågan om vems synvinkel på vilka problem och vilka lösningar som skrivs fram intressant (Ball, 2017). Artikeln handlar alltså inte bara om berättelser och ord utan också om konstruktioner av dessa. I en diskursanalys är genomskinlighet viktigt och Bergström och Ekström (2018) förordar bland annat att citat får ta en stor plats $i$ analysen, något jag har eftersträvat $i$ redovisningen av analysen.

Analysen utgår från fyra narrativa dimensioner (Pollitt, 2013, s. 903) och från Bolander och Fejes (2015, s. 97) Foucaultinspirerade frågor, dock i något modifierad form, uppdelade i huvudfråga och underfråga (se tabell 1).

Tabell 1. Analysfragor

\begin{tabular}{|l|l|}
\hline $\begin{array}{l}\text { Narrativa dimensioner } \\
\text { (Pollitt, 2013) }\end{array}$ & $\begin{array}{l}\text { Foucaultinspirerade frågor } \\
\text { (Bolander \& Fejes (2015) }\end{array}$ \\
\hline $\begin{array}{l}\text { Dominanta teman - vilka dominanta } \\
\text { teman går att finna i skrivningarna? }\end{array}$ & a) Hur karaktäriseras retoriken kring dessa? \\
\hline
\end{tabular}




\begin{tabular}{|l|l|}
\hline $\begin{array}{l}\text { Erbjudna lösningar och evidensbas - } \\
\text { vilka erbjudna lösningar på de beskrivna } \\
\text { problemen ges? Hur mycket och vilka } \\
\text { belägg ligger till grund för problemen och } \\
\text { de erbjudna lösningarna? }\end{array}$ & $\begin{array}{l}\text { b) Vad framställs som god skolutveckling? } \\
\text { Vem eller vilka är upphovspersonerna } \\
\text { bakom evidensbasen? }\end{array}$ \\
\hline $\begin{array}{l}\text { Stil och presentation - hur är texterna } \\
\text { upplagda och presenterade? }\end{array}$ & c) Vad signaleras genom texternas stil? \\
\hline $\begin{array}{l}\text { Viktiga antaganden - finns det viktiga } \\
\text { underliggande antaganden? }\end{array}$ & Vad utesluts eller hamnar i bakgrunden? \\
\hline
\end{tabular}

Analysen visar hur narrativ och diskurser byggs upp, vad dessa gör, vilken bild av verkligheten som produceras genom texterna och vilka sanningsanspråk som dominerar (Bolander \& Fejes, 2015; Fejes, 2006). Läsningen av texterna har gjorts i olika steg, först har alla texterna lästs i sin helhet ett flertal gånger för att på så vis få en övergripande blick av texternas innehåll och karaktär. Därefter lästes texterna utifrån Pollitts (2013) narrativa kategorier och slutligen har Bolander och Fejes (2015) frågor applicerats på de narrativa kategorierna och fokus hamnar då mer på bakomliggande antaganden. Analysen av narrativet och diskursen går i varandra och kan inte helt entydigt separeras till enskilda enheter. Genom att analysen först utgår från tydliga narrativa dimensioner och sedan de Foucaultinspirerade frågorna är intentionen dock att tydliggöra de olika stegen $i$ analysen och därmed göra det möjligt för läsaren att bedöma dess koherens.

\section{RESULTAT - FÖRSTÅELSE UTIFRÅN EN MÖJLIG LÄSNING}

Analysen följer Pollitts (2013) narrativa kategorier utökade med Bolander och Fejes (2015) frågor och presenteras utifrån rubrikerna: 1) Dominanta teman och hur de skrivs fram - samverkan och skräddarsydda insatser, 2) Erbjudna lösningar och evidens - "Bästa skola", 3) Stil och presentation, samt 4) Underliggande antaganden och vad som hamnar i bakgrunden. Först presenteras den narrativa analysen och sedan i sammanfattande form presenteras analysen utifrån de Foucaultinspirerade frågorna under varje rubrik. De aktörer som främst diskuteras i analysen är Skolverket, huvudmän och rektorer.

\section{Dominanta teman och hur de skrivs fram - samverkan och skräddarsydda insatser}

Som själva namnet på skolförbättringsinsatsen Samverkan för bästa skola antyder kan just ordet samverkan antas vara central för SBS. Ordet definieras dock inte i någon av de lästa texterna. Skolverket kommenterar emellertid själva vikten av att tydligt klargöra vad samverkan innebär. Erfarenheterna från en pilotomgång av SBS som genomfördes hösten 2015 pekar på att: 'Det 
finns en risk för att huvudmännen har andra förväntningar på vad samverkan med Skolverket innebär än vad uppdraget anger. Det är därför viktigt att klargöra förutsättningarna för samverkan i ett tidigt skede" (Skolverket, 2016, s. 37). Men, en tydlig definition går alltså inte att finna. På hemsidan finns endast ordet samverkan nämnt i samband med benämning av insatsen Samverkan för bästa skola - istället är det ordet samarbete som används.

Vad som menas med ordet samverkan får istället sökas i texterna och ordet dialog har en central plats när Skolverket beskriver hur samverkan inom SBS ska ske. Samverkan ska bygga på ett "dialogbaserat arbetssätt" (se bl.a. Skolverket, 2016, s. 7). Skolverket ska vidare verka "för ett positivt, framåtsyftande och respektfullt samtalsklimat genom att arbeta med fördjupande och utmanande frågor i kombination med ett inlyssnande förhållningssätt" (Skolverket, 2016, s. 7). Om vi tittar närmare på vad som skrivs om det dialogbaserade arbetssätt så framträder en något motsägelsefull bild av vad som läggs in i begreppet:

I ett dialogbaserat arbetssätt behöver Skolverkets team vara kompetenta och lyhörda dialogpartners, som är öppna för målgruppernas behov samtidigt som nationella mål och rikttinjer tydligt hävdas. I dialogen med huvudmän och rektorer är Skolverkets roll att bidra till ett fördjupat lärande genom att verka för ett positivt, framåtsyftande och respektfullt klimat, ställa fördjupande och utmanande frågor, lyssna in deltagarnas synpunkter och diskussioner samt kommunicera på ett klargörande, relevant och lättbegriplig sätt. (Skolverket, 2016, s. 15 , mina kursiveringar)

Å ena sidan beskrivs det hur Skolverket som part ska vara "lyhörda" och "öppna" för att i samma mening sedan tydligt "hävda" de nationella målen. Orden lyhörd och öppen kan sägas ligga i linje med ordet dialog, medan valet av ordet hävda kan tyckas stå i skarp kontrast till en insats som talar om samverkan och dialog. Vilken roll som Skolverket tar i dessa dialoger kan också i exemplet ses som oklar. I första meningen benämner de sig själva som just dialogpartners för att i sista meningen ställa sig som den drivande dialogägaren genom att positionera huvudmän och rektorer som deltagare. Dessa antas vara i behov av en lättbegriplig kommunikation från dialogägaren, Skolverket. Vad samverkan innebär kan också läsas in i några av de nyckelbegrepp som anges i genomförandeplanen för SBS: dialogbaserat arbetssätt, dialogteam, processtödjare, processtöd. Att SBS ska baseras på dialog och process är tydligt. I Skolverkets beskrivning av vad processstödjarnas uppdrag innebär skriver de att de ska "förmedla och hävda nationella mål på ett tydligt sätt och samtidigt visa respekt och förstäelse för lokala förhållanden, vilket ställer höga krav på förmågan att skapa ett tillitsfullt, öppet samtalsklimat och balansera rollen som stödjande respektive styrande" (s. 23, min kursivering). Ser vi till det första ledet av citatet så pekar det i riktningen mot 
ytterligare ett dominerande tema som kan ses i genomförandeplanen; den om lokala förhållanden och skräddarsydda insatser:

\begin{abstract}
Skolverket anordnar och finansierar insatserna på olika sätt. Förutom att underlätta möjligheten att ta del av Skolverkets pågående utvecklingsinsatser sker samordning av insatser för flera huvudmän med samma behov via externa lärosäten, genom att Skolverket anlitar konsulter för skeräddarsydda insatser till en huvudman/skolenhet eller genom att Skolverket finansierar insatser som huvudmannen själv anordnar. (Skolverket, 2016, s. 36, min kursivering)
\end{abstract}

Även i övriga skrivningar om de insatser som Skolverket anordnar anas ett löfte om skräddarsytt. Skolverket och huvudmän ska genom dialog "identifiera vilka specifika insatser som behöver genomföras på varje utvald skolenhet" (Skolverket, 2016, s. 1, min kursivering). På Skolverkets hemsida går också att läsa att Skolverkets uppdrag är att stärka skolorna och huvudmännen "i arbetet med att planera, följa upp och utveckla utbildningen efter deras unika mål och behov" (min kursivering). Löftet om specifika insatser utifrån unika mål och behov återfinns även det på flera håll i genomförandeplanen, men vad som också betonas är att redan befintliga initiativ från Skolverket bör användas så långt som möjligt, vilket kan peka på en spänning mellan synergieffekter och uttalanden om "skräddarsydda" insatser:

För att möjliggöra synergieffekter ska Skolverket så långt som möjligt samordna denna satsning med andra satsningar som kan tillföra uppdraget mervärde, t.ex. regeringens åtgärder inom den nationella samlingen för läraryrket, nationella skolutvecklingsprogram, insatser för nyanlända elever och kompetensutveckling för lärare och förskollärare. (Skolverket, 2016, s. 5-6; Utbildningsdepartementet, 2015, s. 2)

Ovanstående citat pekar på att det är tydligt att de lösningar som Skolverket ska "komma överens" (Utbildningsdepartementet, 2015, s. 1) med huvudmännen om ska samordnas med redan befintliga insatser från Skolverkets sida. I genomförandeplanen genomgående poängteras att det just är befintliga lösningar som ska användas samtidigt som talet om de unika skräddarsydda lösningarna återkommer. Talet om unika mål och specifika förutsättningar går inte att finna i regeringsbeslutet utan där framstår Skolverket som de som ska erbjuda lösningar och så långt det är möjligt samordna dessa med redan befintliga lösningar. Det kan tolkas som kostnadseffektiva lösningar istället för unika och skräddarsydda lösningar.

I linje med talet om skräddarsydda lösningar synliggörs också talet om att ta hänsyn till lokala förutsättningar. Dialog och hänsyn till de lokala förutsättningarna går hand $i$ hand genom hela genomförandeplanen, men ett stråk 
av dubbelhet kan samtidigt läsas in även här. Skolverket hänvisar till skriften Så gör vi skillnad (2014) när de säger att:

Forskning om skolutveckling visar att staten beböver ta bänsyn till lokala förutsättningar och behov, ge ansvar till huvudmän, rektorer och lärare och skapa en dialog mellan de nivåer som är involverade i skolutvecklingen ((stat - huvudmän - skolor) Staten behöver se huvudmän, rektorer och lärare som medskapare $i$ insatser, istället för att exempelvis se lärare som mottagare av någon annans kunskap. (Skolverket, 2016, s. 15, mina kursiveringar)

Skolverket talar här om maktrelationen mellan stat och lokala aktörer och vikten av att se de lokala aktörerna som jämbördiga i relationen.

Sammanfattningsvis så pekar retoriken kring de dominerande teman som redovisats, samverkan och skräddarsydda insatser, på att det finns en dubbelhet i uttalandena kring dessa. Å ena sidan ska Skolverket vara lyssnande och anpassa till lokala behov, men å andra sidan ska de hävda nationella mål och använda befintliga Skolverksinsatser. Det är kanske i sig inte konstigt att staten förordar kostnadseffektiva lösningar, men det som blir intressant är att det från myndighetens sida lockas med skräddarsytt och att det ska ske på de lokala aktörernas villkor. Talet om att lokala aktörer och Skolverket tillsammans ska hitta de rätta skräddarsydda lösningarna är framför allt mycket framträdande på Skolverkets hemsida vilket visar på en medvetenhet att, i en era av decentraliering där styrningen sker på distans och där det ges en bild av att de lokala aktörerna har stor autonomi, behöver det retoriska talet handla om underifrånperspektivet och de lokala förutsättningarna (jfr Bergh, 2015; Hudson, 2007). I kontrast till talet om underifrånperspektivet står dock det auktoritativa talet gällande att hävda vad som fungerar och att använda befintliga skolverksinsatser i genomförandeplanen, där viljan till ovanifrånstyrning slår igenom (jfr Clarke \& Hollingsworth, 2002; Day \& Sachs, 2004; Sülau, 2019). I genomförandeplanen kan också Skolverket ses både i positionen som dialog- och kunskapsägare och som en jämbördig part i relationen till de lokala aktörerna. Den förstnämnda positionen är dock den som dominerar i de analyserade texterna vilket ligger i linje med Dahlberg och Hertzbergs (2011) resonemang om överordning och underordning i samverkan. Detta leder oss över till det andra ledet i SBS - bästa skola. Vilka lösningar erbjuds och vilka är beläggen för dessa?

\section{Erbjudna lösningar och evidens - "Bästa skola"}

Bästa skola är det andra ledet av namnet Samverkan för bästa skola. Vilka erbjudna lösningar och evidensbas (dvs. belägg) ges för att nå den bästa skolan i skrivningarna i de analyserade texterna? Vad är det som huvudmän och skolor inte gör tillräckligt bra enligt regeringsuppdraget? Syfte med SBS är att: "höja kunskapsresultaten och öka likvärdigheten inom och mellan skolor" 
(Utbildningsdepartementet, 2015, s. 1). De lösningar som ska erbjudas ska alltså syfta till att höja kunskapsresultaten och skapa en mer likvärdig skola. En relativt stor del av regeringsbeslutet ägnas åt att ge stöd för uttalandet att en likvärdig utbildning inte finns idag. Regeringsbeslutet stödjer sig bland annat på Skolverkets rapporter, Skolinspektionens granskningar och internationella rapporter (såsom Improving schools in Sweden: An OECD perspective, OECD, 2015) som stöd för detta uttalande. De insatser som ska genomföras ska enligt regeringsbeslutet vara inriktade på att: "stärka huvudmännens förmåga att planera, följa upp och utveckla utbildningen så att kunskapsresultaten i de utvalda skolorna höjs och likvärdigheten inom och mellan skolorna ökar" (Utbildningsdepartementet, 2015, s. 1).

Skolverket anger sedan i genomförandeplanen fokus för de insatser som ska göras, det vill säga lösningarna på de problem som skrivs fram i regeringsbeslutet. Vad som är bästa skola skrivs inte explicit fram, men genom Skolverkets fokus på insatserna kan det anas vad önskvärd skolutveckling innebär:

Insatserna förväntas leda till att undervisningens kvalitet utvecklas i de medverkande skolorna så att kunskapsresultaten böjs och likvärdigheten ökar inom och mellan de utvalda huvudmännens skolor. För att nå dessa effekter genomför Skolverket dels insatser för att förbättra huvudmännens och skolornas systematiska kvalitetsarbete, dels insatser för att stärka rektorernas pedagogiska ledarskap och för att utveckla lärarnas förmåga att utveckla kvaliteten $i$ undervisningen med fokus på elevernas kunskapsresultat. (Skolverket, 2016, s. 1, mina kursiveringar)

De lösningar som erbjuds är alltså systematiskt kvalitetsarbete och pedagogiskt ledarskap. Den tredje punkten kan upplevas som något oklar, men att lärarna ska bli bättre genom någon form av systematiskt kvalitetsarbete kan läsas in i citatet. Av detta skulle kunna utläsas att den bästa skolan har ett bra systematiskt kvalitetsarbete, rektorerna har ett förstärkt pedagogiskt ledarskap och lärarna har en god förmåga att utveckla kvaliteten $i$ undervisningen och fokus för alla är elevernas kunskapsresultat. Skolans hela uppdrag omnämns i genomförandeplanen:

Beträffande elever som inte fullföljer sina studier visar undersökningar att en viktig orsak ofta är brister i skolans värdegrundsarbete. Insatserna måste därför bidra till att utveckla skolans hela uppdrag, som anger att elever ska ges möjlighet att utveckla såväl kunskaper som värden. (Skolverket, 2016, s. 17)

Det är dock tydligt att det är kunskapsresultaten som står i fokus för erbjudna lösningar i genomförandeplanen: "I arbetet med nulägesanalysen är Skol- 
verkets roll att agera processtöd och säkerställa att utveckling av elevernas kunskapsresultat hela tiden är i fokus" (s. 18, min kursivering). En kvantitativ räkning av hur många gånger värdegrunden/värden/hela uppdraget nämns i genomförandeplanen och hur många gånger kunskapsresultat nämns ger siffrorna 4-42. Fokus gällande de erbjudna lösningarna är tydligt på kunskapsresultat vilket också är det som anges i regeringsuppdraget.

Gällande evidensbasen till SBS så anges i regeringsbeslutet (2015) Skolverksrapporter, Skolinspektionsrapporter, OECD:s rapport Improving schools in Sweden: An OECD perspective (2015) och internationella mätningar såsom PISA och PIRLS. I Skolverkets genomförandeplan finns hänvisningar till flera olika publikationer. Siffrorna som här anges hänvisar till antalet enskilda publikationer och inte antalet gånger de förekommer i texten. Vid en genomgång av angivna publikationer $\mathrm{i}$ noterna $\mathrm{i}$ genomförandeplanen så framkommer det att de flesta av noterna hänvisar till Skolverkets egna rapporter, sexton hänvisningar, två till Myndigheten för skolutveckling medräknat. En skolinspektionsrapport, fyra övriga rapporter (varav två är från danska och norska myndigheter) och två regeringsskrifter hänvisas också till i genomförandeplanen. Utöver myndighetsrapporter finns det tretton referenser till olika böcker varav alla utom en är skrivna av forskare. Tio av referenserna till böckerna anges $i$ en och samma not.

Förutom detta finns även två referenser till forskningslitteratur, en artikel (Manger \& Novak, 2012 [sic! Nowak]) och en avhandling (Wilhelmsson, 1998). Vad gäller internationella mätningar och rapporter finns det tre hänvisningar. De internationella satsningarna som Skolverket anger som inspirationskällor till SBS är den norska satsningen Veilederkorps (Vägledningsteam). Ett skolutvecklingsprogram från England nämns också där så kallade framgångsrika och sämre skolor bildar nätverk. Programmet drivs idag av stiftelsen Challenge Partners och den enda hänvisningen som görs är till stiftelsens hemsida. Även skolutvecklingsprojekt i Ontario i Kanada nämns med referens till McKinsey \& Company (Barber et al., 2010).

Skolverket diskuterar tidigare erfarenheter gjorda av Skolverket och Myndigheten för skolutveckling i deras utvecklingsdialoger som pågick 20012008. En av erfarenheterna är "att stödja och utveckla redan pågående, planerat eller påtänkt utvecklingsarbete" (Skolverket, 2016, s. 26), vilket kan tyckas stå i motsats till att använda befintliga insatser från Skolverket. Ett annat projekt som nämns är Handledning för lärande som genomfördes av Skolverket 2012-2014 och en lärdom därifrån är:

att insatserna kunde ha fått en ännu större effekt och också haft större möjligheter att bli långsiktigt hållbara om uppdraget hade varit mer öppet formulerat. Större flexibilitet hade ökat möjligheterna att koppla insatserna till skolans systematiska kvalitetsarbete och de lokala behoven som identifieras. (Skolverket, 2016, s. 26) 
Öppet formulerade uppdrag, flexibilitet och att stödja befintligt utvecklingsarbete framkommer här som viktiga erfarenheter från tidigare samverkan mellan statliga myndigheter och lokala aktörer. I kontrast till dessa erfarenheter står att finna uttalanden i genomförandeplanen som pekar åt motsatt håll, att insatserna ska bygga på kunskap om "effektiv kompetensutveckling" (Skolverket, 2016, s. 8) och att det lokala utvecklingsarbetet ska "bedrivas på bästa sätt utifrån vetenskap och beprövad erfarenhet" (s. 7). Det ska genomföras en kartläggning och en analys i den lokala verksamheten, men: "Det systematiska kvalitetsarbetet fördjupas med hjälp av generella bilder av vad som fungerar som forskning bidrar med" (s. 16, min kursivering).

Sammanfattningsvis så handlar narrativen $\mathrm{i}$ de analyserade texterna om vad som är problemen i svensk skola, om bristande likvärdighet och sjunkande kunskapsresultat. Lösningarna på dessa problem är systematiskt kvalitetsarbete, pedagogiskt ledarskap och att lärarna ska bli bättre lärare, vilket kan ses som exempel på common sense-lösningar som blivit neutraliserade sanningar (Røvik \& Pettersen, 2014; jfr Börjesson, 2016; Fairclough, 2001). För vad är alternativet - osystematiskt arbete och ett opedagogiskt ledarskap? Fokus gällande de erbjudna lösningarna är tydligt på kunskapsresultat. En dubbelhet gällande att ta hänsyn till lokala förutsättningar och bedriva en effektiv kompetensutveckling baserad på generella bilder av vad som fungerar kan också märkas i talet om hur skolutveckling inom SBS ska bedrivas.

Evidensbasen för de erbjudna lösningarna är till stor del självrefererande, det vill säga Skolverkets egna rapporter är det som anges som stöd för de insatser som ska göras. Andra källor finns, men de av myndigheten producerade rapporterna och skrifterna är det som förekommer mest. Det går att tolka på flera sätt, ett sätt att se på det är att det blir en slags evidenceloop (Nolan, 2015, s. 895) där Skolverkets egna rapporter ges som stöd för att legitimera den kunskap som de producerar. Det kan också ses som en form av övertalning om det rätta sättet att göra skolutveckling där Skolverket söker stöd i de egna texterna. Forskare finns med som referenser, men stor koncentration av dessa återfinns i en not och bara två referenser kan ses som forskningslitteratur. Två av de tre internationella erfarenheter som refereras till i genomförandeplanen, Challenge Partners och referensen till Ontarioprojektet via McKinsey \& Company, har av vissa forskare också fått en del kritik och skulle kunna härledas till vad många kallat en marknadifiering av skolan med stort inflytande av konsulter och konsultverksamheter (se bl.a. Ball, 2009; Gunter \& Mills, 2017). Rapporten av McKinsey \& Company (Barber et al., 2010) har blivit kritiserad bland annat på grund av att den har en tunn evidensbas, en utarmad syn på lärande och undervisning och att kulturens roll är bagatelliserad (Coffield, 2012).

Evidensbasen som ges i framför allt regeringsbeslutet vilar på en normativ diskurs, baserad på bland annat jämförelsedata såsom PISA och PIRLS (jfr 
Nordin, 2014a). Narrativet är starkt präglat av en internationell policydiskurs där begrepp som resultat, utfall, utvärdering och olika standarder sätts $i$ fokus (Carlbaum et al., 2014; Grek, 2009). Detta väcker frågor om vad som konstitueras som legitim kunskap och vem som får producera den (Nolan, 2015; Røvik \& Pettersen, 2014). De statliga myndigheterna är inte bara de som påverkar den nationella retoriken kring hur skola bör göras, de blir i sin tur påverkade av internationella diskurser gällande vad som anses vara ett legitimt sätt att bedriva skolpolitik (jfr Ball, 2009; Gunter \& Mills, 2017).

\section{Stil och presentation}

Utifrån artikelns huvudfokus att analysera storyn om SBS blir stil och presentation $\mathrm{i}$ de tre analyserade texterna intressant då dessa är, som diskuterats i metod och material, av tre skilda slag med olika målgrupper i åtanke. Regeringsbeslutet har en saklig ton och kan betecknas som en traditionell myndighetstext som är relativt kort (fem sidor) med direktiv och argument för initiativet. Genomförandeplanen är längre (39 sidor) och ordrikare än regeringsbeslutet och innehåller en del upprepningar, dels från beslutet, dels av de egna formuleringarna i genomförandeplanen. Genomförandeplanen är mer explicit gällande strategier för SBS genomförande. Rent layoutmässigt finns det noter där referenser återfinns. Det finns några tabeller och diagram som bland annat illustrerar tidsplanen för SBS och beräknade kostnader för SBS. Tabeller över de huvudmän som påbörjat SBS finns också med. En bilaga som sammanfattar de råd som Skolverket haft inför skrivandet av genomförandeplanen finns sist $i$ texten. Fokus har under tidigare rubriker legat på regeringsbeslutet och genomförandeplanen men här under rubriken stil och presentation kommer ljuset att riktas mot den mer publika hemsidan om SBS på skolverket.se. Det kan motiveras med att det $\mathrm{i}$ genomförandeplanen står att det är den "logiska första källan för att hitta tydlig och utförlig information om vad satsningen innebär och arbetet med den" (s. 24 ).

Som nämndes tidigare utgår analysen av hemsidan från det textmaterial som är läsbart utan att klicka vidare på hemsidan. "Vi stödjer utvalda skolor och förskolor att utvecklas utifrån sina egna behov" är den första mening som möter läsaren av hemsidan. Talet om de lokala behoven känns igen här. Talet om att Skolverket, huvudmän och skolor ska arbeta tillsammans är det som är mest framträdande: "Under tre år erbjuder vi på Skolverket personlig kontakt och hjälp i att hitta olika metoder, arbetssätt och verktyg beroende på vilka utvecklingsbehov som finns". De egna unika behoven som tidigare diskuterats är tydligt framskrivet på hemsidan och orden tillsammans, stödja och samarbeta kan här ses som huvudord: "Tillsammans diskuterar vi tänkbara insatser ...". Presentationen och upplägget på hemsidan ger en bild av att huvudmännen är mer de som är i förarsätet $i$ arbetet jämfört med beskrivningarna i genomförandeplanen: "Med stöd av oss, universitet och högskola, eller 
en konsult, planerar ni för insatserna. Ni som huvudman prioriterar i vilken ordning olika insatser ska genomföras". Som tidigare nämnts är det ordet samarbete som används på hemsidan. "Vi på Skolverket håller kontinuerlig kontakt med huvudmannen under samarbetet och ger fortsatt stöd". Det är alltså ett samarbete och inte en samverkan. Skolverket ska ge stöd och ordet hävdar, som återfinns i genomförandeplanen, finns inte med på hemsidan. Rubrikerna för de två översta reportagen på hemsidan från skolor som deltagit i SBS har ett positivt vokabulär: "en förmån att få delta i SBS" och "Så lyckades ...". På bild syns glada barn.

Sammanfattningsvis är regeringsbeslutet till sin stil en traditionell myndighetstext som signalerar statlig rationalitet. Genomförandeplanen kan också betecknas som en typisk myndighetstext som signalerar att myndigheten Skolverket har tolkningsföreträde för hur skolutveckling bör bedrivas. Beskrivningen av SBS på hemsidan är i positiva ordalag. Glada barn och referenser till lyckade insatser förstärker intrycket av en framgångsrik statlig satsning. Staten samarbetar tillsammans med huvudmän och skolor, men till skillnad från genomförandeplanen skrivs huvudmän och skolor mer fram som de som är de ledande i samverkan/samarbetet. Skolverket positionerar sig här som en jämlik part som ger personlig kontakt och stödjer de lokala aktörerna i ett samarbete. Stilen på hemsidan är mer av marknadsförande art än det mer traditionella regeringsbeslutet och genomförandeplanen och målgruppen för hemsidan är också skolpersonal och allmänhet. Detta kan liknas vid andra studier av offentliga organisationer där identitet och image har blivit allt viktigare (se bl.a. Rehnberg, 2019). Den inbjudande, välvilliga och stödjande retoriken på hemsidan kan också ses som en del av en soft governance-logik där Skolverket framstår som den goda kamraten istället för den reglerande myndigheten.

\section{Underliggande antaganden och vad som hamnar i bakgrunden}

Ett tydligt antagandet är att det finns en NPM-retorik som genomsyrar texterna, där resultat, effektivitet, kvalitet och best practice står i fokus. Kunskapsrationalitet är ett viktigt grundantagande som genomsyrar alla texterna och det problematiseras inte. I genomförandeplanen omnämns som tidigare presenterats - skolans hela uppdrag, men kunskap, effektivitet och måluppfyllelse står i centrum.

Givet det utrymme som ägnas åt kommunernas bristande kompensatoriska resursfördelning i framför allt regeringsbeslutet, men även omnämnt i genomförandeplanen, så skulle bristande kompensatorisk resursfördelning också kunna ses som ett viktigt underliggande antagande för genomförandet av SBS.

Skolverket har också i tidigare rapporter, Resursfördelning utifrån förutsättningar och behov? (rapport 2009:330), Resursfördelning till 
grundskolan - rektorers perspektiv (rapport 2011: 365) samt Kommunernas resursfördelning till grundskolor (rapport 2013:391), visat att det kompensatoriska inslaget $i$ huvudmännens resursfördelning är förhållandevis litet, och att kommunerna inte alltid fördelar efter behov. Skolverket påpekar $\mathrm{i}$ lägesbedömningen att de ökade skillnaderna i skolors resultat kräver kraftfulla åtgärder på nationell och kommunal nivå om likvärdigheten i skolsystemet ska upprätthållas.

(Utbildningsdepartementet, 2015, s. 4)

De lösningar som erbjuds för SBS ligger dock på det organisatoriska planet och inte på det politiska eller ekonomiska, vilket gör att talet om bristande kompensatoriska resursfördelningen stannar vid just talet om. Även elevers socioekonomiska bakgrund diskuteras i regeringsbeslutet och beskrivs där som något som fortsatt spelar stor roll för elevernas prestationer i olika ämnen. I genomförandeplanen nämns elevers socioekonomiska bakgrund som ett urvalskriterium för deltagande i SBS, men diskuteras inte ytterligare.

Ett underliggande antagande $\mathrm{i}$ genomförandeplanen är att Skolverket behöver garantera att elevernas kunskapsresultat är i centrum: 'I arbetet med nulägesanalysen är Skolverkets roll att agera processtöd och säkerställa att utveckling av elevernas kunskapsresultat hela tiden är i fokus" (Skolverket, 2016, s. 18). Skolverkets tillit till att andra behov eller utvecklingsområden inte tar överhand på den lokala arenan tycks konkurrera med ett ännu större behov av att kontrollera skolornas arbete med elevernas kunskapsresultat och systematiskt kvalitetsarbete. Skolverket åberopar också tidigare erfarenheter med arbetet med huvudmän och skolor som visar att de saknar kunskaper i systematiskt kvalitetsarbete:

Erfarenheter visar dock att huvudmän och skolor alltför ofta saknar såväl en tydlig problembild som en resultat- och behovsanalys innan utvecklingsinsatser planeras och genomförs. För att skolornas kunskapsresultat ska höjas och likvärdigheten inom och mellan skolor öka, behöver de utvalda skolenheterna och huvudmännen utveckla en självförnyande förmåga. Ett fungerande systematiskt kvalitetsarbete med en kvalificerad analys utgör grunden för en sådan förmåga. (Skolverket, 2016, s. 16)

Tanken om att skolenheterna och huvudmännen ska utveckla en självförnyande förmåga ligger i linje med governance-logiken där de styrande överför normativa regler som de under rättar sig efter och internaliserar (jfr Hudson, 2007; Vallberg Roth, 2014) och de blir i Foucaults termer sina egna väktare. Talet om ständig förbättring och förnyelse ligger också i linje med det starka fokus som finns på resultat (se tidigare referens internationellt resultatfokus). 
Sammanfattningsvis kan antaganden som ligger i linje med governancetänkandet och den NPM-influerade policydiskursen urskiljas i SBS, med fokus på best practice och på kunskapsresultat (jfr Grek, 2009; Olssen \& Peters, 2005). Gällande de erbjudna lösningar som ges i SBS följer de en fåra av ett underliggande antagande; genom att förändra organisatoriska strukturer och processer så kan huvudmäns och skolors effektivitet förändras. De lokala aktörerna behöver också utveckla en "självförnyande förmåga", något som också kan hänföras till nämnda diskurser (jfr Hudson, 2007). Det som hamnar i bakgrunden, även om det finns med i både regeringsbeslutet och genomförandeplanen, är de möjliga större strukturella orsakerna till att huvudmän och skolor blir utvalda till att delta i SBS: kommuners bristande kompensatoriska resursfördelning och elevers socioekonomiska bakgrund. Andra orsaker som segregation och små kommuner med små resurser omnämns, men lösningarna som diskuteras i SBS adresserar inte dessa mer politiska och ekonomiska frågor och det ligger också kanske utanför ramarna för insatsen. Det skulle kräva andra insatser från statens sida vilket diskuteras vidare i den avslutande diskussionsdelen.

\section{DISKUSSION}

Syftet med studien, var att skriva fram ett tänkbart narrativ om SBS, utifrån tre offentliga texter, för att synliggöra och lyfta fram underliggande diskurser i retoriken kring SBS. Resultatsektionen har främst fokuserat på studiens övergripande fråga - vad är storyn om SBS i de analyserade texterna? I sammanfattningarna till resultatavsnitten har frågorna om vilka diskurser som går att utläsa i storyn samt frågan om vilka subjektspositioner som går att finna även diskuterats. I den avslutande diskussionen förs en mer övergripande diskussion utifrån studiens frågor. Att göra en narrativ diskursanalys innebär att jag både har fokuserat på storyn om SBS och hur den skrivs fram (Bolander \& Fejes, 2015; Robertson, 2017). Det är inte sanningen om SBS som skrivits fram, utan en möjlig läsning av fenomenet har presenterats utifrån ett styrningsraster med utgångspunkt i governance, governmentality och samverkan.

Samverkan eller styrning är frågan. Kan det vara både och? Det går att finna många uttalanden som tyder på att det är den sistnämnda rollen som är den dominerande i de texter om SBS som analyserats. Det finns en stor tonvikt i texterna på att huvudmän och skolor ska ta del av befintliga skolutvecklingssatsningar som Skolverket ger. Staten strävar på detta sätt efter att styra genom information, soft governance (Hudson, 2007; Kirsten \& Wermke, 2017; Moos, 2009). Samverkan kan sägas ge sken av nätverksstyrning (Olsson et al., 2019), eller NPG (Osborne, 2010). Läsningen av texterna ger dock bilden av mer traditionell PA och NPM (Osborne, 2010). De diskurser som har identifierats i resultatet är både talet om skolutveckling som bygger på 
ovanifrånperspektivet och skolutveckling som bygger på underifrånperspektivet. Dessa två förutsätter två olika subjekt. Den förstnämnda ser lokala aktörer som mottagare av nationell utbildningspolitik och den andra ser de lokala aktörerna som aktiva medskapare. Den här dubbelheten kan vara problematisk i en satsning som utger sig för att bygga på samverkan. Det finns en risk att samverkan används som ett retoriskt knep (Hargreaves \& Goodson, 2003) och att begreppet samverkan blir ett ord som ska ge SBSinsatsen ett positivt skimmer (se Lindberg, 2009). Utifrån den här läsningen av SBS är storyn på ytan en berättelse om hur samverkan och dialog ska hjälpa de fallerande huvudmännen och skolorna - Skolverket som den goda och stödjande myndigheten vilket framför allt analysen av hemsidan pekar på. Men då artikeln har använt kritiska frågor för att försöka komma under ytan på storyn om hur samverkan löser allt, har också en story om viljan till styrning framkommit. Relationen mellan stat och kommun kan i de lästa texterna betecknas som en relation mellan överordnad och underordnad, vilket ligger i linje med ovanifrånperspektiv (Olsson et al., 2019; jfr Dahlstedt \& Hertzberg, 2011). Då SBS utgår från ett negativt urval accentueras bristperspektivet trots formuleringar i texterna och talet om huvudmän och skolor som "medskapare" (Skolverket, 2016, s. 15). Huvudmän och skolor tycks i stor utsträckning få positionen som mottagare av de "rätta" kunskaperna (Clarke \& Hollingsworth, 2002; Day \& Sachs, 2004; Sülau, 2019). Skolverket ska se till att skolenheterna och huvudmännen skaffar sig en "självförnyande förmåga", en tanke som ligger i linje med governancetänkandet (Hudson, 2007) och även Foucaults (2008) tanke om governmentality: styrning genom att huvudmän och skolor anammar Skolverkets sätt att tänka. Evidenceloopen - den höga andelen av självrefererande texter som lyftes fram i analysen kan också ses som ett exempel på detta. SBS skulle kunna ses som ett exempel där staten stärker sin makt över skolan vilket ligger i linje med andra reformer såsom fler nationella prov och en förstärkt skolinspektion (Lundström, 2018; Nordin, 2014a, 2014b). Det är lätt att mer statlig makt tolkas som att det vore något negativt, men relationen mellan autonomi och kontroll är inte ett nollsummespel (Cribb \& Gewirtz, 2007).

Det stora fokus på kunskapsresultaten som genomsyrar SBS går hand i hand med tanken om människan som en ekonomisk varelse och där utbildning blir en ekonomisk strävan efter att bli en ledande kunskapsnation (Carlbaum et al., 2014; Säfström, 2005) och följden av det blir konkurrens, mätbarhet och en ständig jämförelse mellan länder, organisationer och elever (Nordin, 2014a). Denna diskurs influerad av NPM riskerar att leda till begränsningar i vad som är acceptabel skolutveckling (jfr Ball, 1993). I denna mening är staten inte bara den som producerar diskurser utan också en produkt av en större global diskurs påverkad av olika globala sanningsregimer (Sahlberg, 2016, jfr Fejes, 2006). Det kan också ses genom att de fyra 
skolutvecklingsstrategier som pekats ut som typiska i vår tid, kvalitet, ledning, accountibility och evidensbaserad praktik (Røvik \& Pettersen, 2014), finns alla representerade i SBS. Adolfsson och Sundberg (2018) lyfter fram att det finns en risk att talet om "what works" och effektiv skolutveckling passiviserar skolans personal om det används på ett alltför instrumentellt sätt.

Ett antal spänningar har också lyfts fram, spänningen mellan det skräddarsydda och det generella, mellan att hävda och föra dialog. I resultatet går också att utläsa en spänning mellan decentralisering och kontroll. Narrativen om de lösningar på problemen som framställs i SBS ligger i linje med accountibility - skulden ligger på den lokala nivån och genom självreglering ska skolan bli bättre (jfr Hudson, 2007; Perryman, 2007). Ball (2017) beskriver också detta som en global rörelse där fokus ligger på resultaten genom effektivitet och kvalitet där staten styr på distans. En fråga som artikeln väckt är om detta skymmer sikten för större problem som ligger på en mer politisk och ekonomisk nivå. Winther Jörgensen och Philips (2000) skriver om hur subjektifieringen $i$ vårt samhälle gör att vi som individer blir ansvariga för att lösa de problem som kommer i vår väg istället för att de ses som allmänna problem som kräver kollektiva lösningar. Det blir en subjektifiering av de huvudmän och skolor som ingår där ansvaret för att lösa problemen blir deras. Skolverket och konsulter bistår med information och stöd angående den rätta vägen att lösa problemen på, istället för att se skolans problem som allmänna problem som kräver kollektiva lösningar. Maktutövningen i SBS kan sägas styras genom en NPM-diskurs som letat sig in i skolans värld (jfr effektivitet och mätbarhet). Kombinationen av decentralisering och kontroll framstår som rationell och gör de enskilda individerna till ansvariga (Alvesson, 2002).

För att återknyta till Foucaults (2008) begrepp governmentality så innebär policy alltid både govern (styrning) och mentality (inställning) (Hultqvist \& Petersson, 1995) vilket denna artikel har belyst och diskuterat. Policypropåer från staten styr både direkt innehåll och hur, i SBS fall, skolutveckling bör göras, men det styr också mer indirekt genom att det påverkar människors inställningar, vad som är tänkbart, görbart och sägbart inom ett visst område (Bacchi, 2000; Ball, 1993, 2006). Detta kan också liknas vid NPG (Osborne, 2010) då både governmentality och NPG handlar om att via mjukare former av styrning få människor att agera på ett önskvärt sätt. Studiens kunskapsbidrag är att den kritiskt granskar en satsning som omgärdas av common sense-ideologi och för ett resonemang om de underliggande antaganden som identifierats $\mathrm{i}$ analysen. Att vara kritisk betyder inte att säga hur saker egentligen är utan vad diskursanalyser av detta slag kan bidra med är att lyfta blicken från dessa underliggande common sense-antaganden som genomsyrar offentliga texter och på så sätt öppna upp för alternativa tankesätt och handlingssätt (Foucault, 1988). Den här artikelns fokus har legat på analysen av statliga texter rörande SBS. Som redan diskuterats är de tre analyserade 
texterna av olika slag med skilda mottagare i fokus och de tillhör skilda genrer av offentliga texter. Detta skulle kunna påverka analysen och medverka till skevhet (Bryman, 2016) när narrativet skrivs fram. Dock kan texternas olikhet också ses som studiens styrka. I och med att olika typer av officiella texter analyserats har det funnits möjlighet att ge en mer allsidig bild av SBS. Utifrån Balls (1993) definition av policy kan även hemsidans text ses som en form av policytext som har till syfte att påverka människors inställningar. Vidare behöver studien kompletteras med mer empiriskt inriktad forskning för att närmare undersöka mottagandet och förståelsen av SBS hos de utvalda huvudmännen och skolorna.

\section{NOTER}

${ }^{1}$ Där kan grundskolan söka 67 statsbidrag (2019 och 2020) och det finns för närvarande åtta nationella skolutvecklingsprogram innehållande många olika utbildningsinsatser riktade till olika målgrupper inom skola. Se Skolverkets hemsida: https://www.skolverket.se/skolutveckling/nationella-skolutvecklingsprogram ${ }^{2}$ Urvalskriterierna har ändrats något sedan framskrivandet av de i studien ingående texterna (se Skolverket, 2019a).

${ }^{3}$ Utskriftsdatum 191211. Analysen av hemsidan utgår från det textmaterial som läsaren möts av vid första anblick på hemsidan. Klickbara länkar och video- och ljudmaterial har inte analyserats. Ungefär hälften av dessa sidor innehåller videooch ljudreportage från skolor och huvudmän som deltagit i SBS.

\section{REFERENSER}

Adolfsson, Carl-Henrik, \& Sundberg, Daniel (2018). Att forskningsbasera den svenska skolan - policyinitiativ under 25 år. Pedagogisk. Forskning i Sverige, 23(1-2), 39-63.

Alvesson, Mats (2002). Kommunikation, makt och organisation. Kritiska tolkningar av ett informationsmöte $i$ ett företag (2. uppl.). Nordstedts juridik.

Alvesson, Mats, \& Sköldberg, Kaj (2008). Tolkning och reflektion. Vetenskapsfilosofi och kvalitativ metod (2. uppl.). Studentlitteratur.

Bacchi, Carol (2000). Policy as Discourse: What does it mean? Where does it get us? Discourse: Studies in the Cultural Politics of Education, 21(1), 45-57. doi:10.1080/01596300050005493

Ball, Stephen J. (1993). What is policy? Policy: texts, trajectories and toolboxes. Discourse, 13(2), 10-17. https://doi.org/10.1080/0159630930130203

Ball, Stephen J. (2006). Education policy and social class: The selected works of Stephen J. Ball. Routledge. 
Ball, Stephen J. (2009). Privatising education, privatising education policy, privatising educational research: network governance and the 'competition state'. Journal of Education Policy, 24(1), 83-99. DOI: 10.1080/02680930802419474

Ball, Stephen J. (2015). What is policy? 21 years later: reflections on the possibilities of policy research. Discourse: Studies in the Cultural Politics of Education, 36(3), 306313. http:/ /dx.doi.org/10.1080/01596306.2015.1015279

Ball, Stephen J. (2017). The Education Debate (3. uppl.). Policy Press.

Barber, Michael, Chijioke, Chinezi, \& Mourshed, Mona (2010). How the world's most improved school systems keep getting better. McKinsey \& Company.

Bengtsson, Hans, \& Melke, Anna (2019). Vår offentliga förvaltning. Samverkan i välfärdspolitiken. (2. uppl.). Gleerups.

Bergh, Andreas (2015). Local educational actors doing of education - a study of how local autonomy meets international and national quality policy rhetoric. Nordic Journal of Studies in Educational Policy, 2, 42-50. DOI: 10.3402/nstep.v1.28146.

Bergström, Göran, \& Ekström, Linda (2018). Tre diskursanalytiska inriktningar. I Kristina Boréus \& Göran Bergström (Red.), Textens mening och makt. Metodbok i sambällsvetenskaplig text- och diskursanalys (4. uppl., s. 253-301). Studentlitteratur.

Bergström, Göran, Ekström, Linda, \& Boréus, Kristina (2017). Discourse Analysis. In Kristina Boréus \& Göran Bergström (Red.), Analyzing Text and Discourse. Eight Appraoches for the Social Sciences (s. 208-241). Sage.

Bolander, Eva, \& Fejes, Andreas (2015). Diskursanalys. I Andreas Fejes \& Robert Thornberg (Red.), Handbok $i$ kvalitativ analys (s. 91-115). Liber.

Bradbury, Alice, McGimpsey, Ian, \& Santori, Diego (2013). Revising rationality: the use of 'Nudge' approaches in neoliberal education policy. Journal of Education Policy, 28(2), 247-267. DOI: 10.1080/02680939.2012.719638

Bryman, Alan (2018). Sambällsvetenskapliga metoder (3. [rev.] uppl.). Liber.

Börjesson, Mats (2003). Diskurser och konstruktioner. En sorts metodbok. Studentlitteratur.

Börjesson, Mattias (2016). Från likvärdighet till marknad. En studie av offentligt och privat inflytande över skolans styrning i svensk utbildningspolitik 1969-1999.

(Doktorsavhandling. Örebro Studies in Education 52 och Örebro Studies in Educational Sciences with an Emphasis on Didactics 14). Örebro universitet.

Cardini, Alejandra (2006). An analysis of the rhetoric and practice of educational partnerships in the UK: an arena of complexities, tensions and power. Journal of Education Policy, 21(4), 393-415. DOI: 10.1080/02680930600731773

Carlbaum, Sara, Hult, Agneta, Lindgren, Joakim, Novak, Judit, Rönnberg, Linda, \& Segerholm, Christina (2014). Skolinspektion som styrning. Utbildning \& Demokrati, 23(1), 5-20. 
Clarke, David, \& Hollingsworth, Hilary (2002). Elaborating a model of teacher professional growth. Teaching and Teacher Education 18(8), 947-967. DOI: 10.1016/S0742-051X(02)00053-7

Coffield, Frank (2012). Why the McKinsey reports will not improve school systems. Journal of Education Policy, 27(1), 131-149. DOI: 10.1080/02680939.2011.623243

Cribb, Alan, \& Gewirtz, Sharon (2007). Unpacking Autonomy and Control in Education: some conceptual and normative groundwork for a comparative analysis. European Educational Research Journal, 6(3), 203-213. https://doi.org/10.2304/eeri.2007.6.3.203

Dahlstedt, Magnus, \& Hertzberg, Fredrik (2011). Skola $i$ samverkan. Miljonprogrammet och visionen om den öppna skolan. Gleerups.

Danermark, Berth (2004). Samverkan - en fraga om makt. Läromedia.

Danermark, Berth, \& Kullberg, Christian (1999). Samverkan. Välfärdens nya arbetsform. Studentlitteratur.

Day, Christopher, \& Sachs, Judyth (2004). International handbook on the continuing professional development of teachers. Open University Press.

Fairclough, Norman (2001). Language and Power. (2. Uppl.). Longman.

Fejes, Andreas (2006). The planetspeak discourse of lifelong learning in Sweden: what is an educable adult? Journal of Education Policy, 21(6), 697-716. DOI: $10.1080 / 02680930600969266$

Fink, Dean, \& Stoll, Louise (2005). Educational Change: Easier Said than Done. I Andy Hargreaves (Red.), Extending Educational Change. International Handbook of Educational Change (s. 17-41). Springer.

Foucault, Michel. (1972). The archaeology of knowledge and the discourse on language. Pantheon.

Foucault, Michel (1980). Power/Knowledge: Selected Interviews and Other Writings, 19721977 (Red. Colin Gordon). Pantheon.

Foucault, Michel (1988). Practicing criticism. I Lawrence D. Kritzman (Red.), Politics, philosophy, culture: Interviews and other writings 1977-1984 (s. 152-156). Routledge.

Foucault, Michel (2008). Diskursernas kamp. Texter i urval av Thomas Götselius \& Ulf Olsson. Brutus Östlings Bokförlag Symposion.

Graham, Linda J. (2005). Discourse analysis and the critical use of Foucault. [Paper presentation]. Australian Association for Research in Education Annual Conference, Sydney, 27th November - 1st December. Tillgänglig: http://www.forschungsnetzwerk.at/downloadpub/2689 2005.pdf

Grek, Sotiria 2009. Governing by Numbers: The PISA Effect in Europe. Journal of Education Policy 24(1), 23-37. https://doi.org/10.1080/02680930802412669 
Gunter, Helen M., \& Mills, Colin (2017). Consultants and Consultancy: the Case of Education. Springer.

Hargreaves, Andy, \& Goodson, Ivor F. (2003). Teachers' Professional Lives: Aspirations and Actualities. I Andy Hargreaves \& Ivor, F. Goodson (Red.), Teachers' Professional Lives (3. uppl., s. 1-27). Falmer Press.

Holmdahl, Gudrun (2011). Skolutveckling som diskursiv praktik. Nägra ideologiska implikationer. (Doktorsavhandling. Karlstad University Studie 2011:37). Universitetstryckeriet. Tillgänglig: http://www.divaportal.org/smash/get/diva2:433046/FULLTEXT01.pdf

Hudson, Christine (2007). Governing the Governance of Education: the state strikes back? European Educational Research Journal, 6(3), 266-282. https://doi.org/10.2304/eerj.2007.6.3.266

Hultqvist, Kenneth, \& Petersson, Kenneth (1995). Nutidshistoria: några inledande utgångspunkter. I Kenneth Hultqvist \& Kenneth Petersson (Red.), Foucault namnet på en modern vetenskeaplig och filosofisk problematik (s. 16-37). HLS Förlag.

Kirsten, Nils, \& Wieland, Wermke (2017). Governing teachers by professional development: state programmes for continuing professional development in Sweden since 1991. Journal of Curriculum Studies, 49(3), 391-411. DOI: 10.1080/00220272.2016.1151082

Lindberg, Kajsa (2009). Samverkan. Liber.

Lindberg, Mats (2017). Qualitative Analysis of Ideas and Ideological Content. I Kristina Boréus \& Göran Bergström (Red.), Analyzing Text and Discourse. Eight Approaches for the Social Sciences (s. 86-121). Sage.

Lundahl, Lisbeth (2007). Swedish, European, global: the transformation of the Swedish welfare state. I Bob Lingard \& Jenny Ozga (Red.), The RoutledgerFalmer Reader in Education Policy and Politics (s. 117-130). Routledge.

Lundström, Ulf (2018). Lärares professionella autonomi under New Public Management-epoken. Utbildning \& Demokrati 27(1), 33-59.

Magnusson, Eva Maria (2018). Vad händer i själva verket? Om styrning och handlingsutrymme i Skolverket under aren 1991-2014. (Doctoral thesis /

Företagsekonomiska institutionen, Uppsala universitet 192.) Företagsekonomiska Institutionen.

Montin, Stig, \& Hedlund, Gun (2009). Governance som interaktiv samhällsstyrning - gammalt eller nytt i forskning och politik? I Hedlund, Gun \& Montin, Stig (Red.), Governance på svenska (s. 7-36). Santérus Academic Press Sweden.

Moos, Lejf (2009). Hard and Soft Governance: the journey from transnational agencies to school leadership. European Educational Research Journal, 8(3), 397-406. doi.org/10.2304/eerj.2009.8.3.397

Nolan, Kathleen (2015). Neoliberal common sense and race-neutral discourses: a critique of "evidence-based" policy-making in school policing. Discourse: Studies in 
the Cultural Politics of Education, 36(6), 894-907.

http:/ /dx.doi.org/10.1080/01596306.2014.905457

Nordin, Andreas (2014a). Crisis as a discursive legitimation strategy in educational reforms: A critical policy analysis. Education Inquiry, 5(1), 109-126. DOI: 10.3402/edui.v5.24047

Nordin, Andreas (2014b). Centralisering i en tid av decentralisering: Om den motsägelsefulla styrningen av skolan. Utbildning och Demokrati. 23(2), 27-44.

OECD (2015). Improving schools in Sweden. An OECD perspective. Paris: Organization for Economic Co-operation and Development.

Olssen, Mark \& Peters, Michael A. (2005). Neoliberalism, higher education and the knowledge economy: From the free market to knowledge capitalism. Journal of Education Policy, 20(3), 313-345. https://doi.org/10.1080/02680930500108718

Olsson, Jan, Berg, Monika, Hysing, Erik, Kristianssen, Ann-Catrin \& Petersén, Anna (2019). Policy i teori och praktik. Studentlitteratur.

Osborne, Stephen P. (2010). Introduction. The (New) Public Governance: a suitable case for treatment? I Stephen P. Osborne (Red.), The New Public Governance? Emerging Perspectives on the Theory and Practice of Public Governance (s. 1-16). Routledge.

Paltridge, Brian (2012). Discourse Analysis (2. uppl.) Bloomsbury.

Perryman, Jane (2007). Inspection and Emotion. Cambridge Journal of Education, 37(2), 173-190. DOI: 10.1080/03057640701372418

Pierre, Jon \& Peters, Guy B. (2000). Governance, Politics and the State. Macmillan.

Pollitt, Christopher (2013) The Evolving Narratives of Public Management Reform. Public Management Review, 15(6), 899-922, DOI: 10.1080/14719037.2012.725761

Pollitt, Christopher, \& Hupe, Peter (2011). Talking About Government. The role of magic concepts. Public Management Review, 13(5), 641-658. DOI: 10.1080/14719037.2010.532963

Pollitt, Christopher, \& Bouckaert, Geert (2011). Public Management Reform. A Comparative Analysis: new public management, governance, and the neo-Weberian state. Oxford University Press.

Popkewitz, Thomas, \& Lindblad, Sverker (2000). Educational Governance and Social Inclusion and Exclusion: some conceptual difficulties and problematics in policy and research. Discourse: studies in the cultural politics of education, 21(1), 5-44. DOI: $10.1080 / 01596300050005484$

Rehnberg, Hanna Sofia (2019). Trafikverket - en modern samhällsutvecklare eller en talför svensk man? Myndighetsrepresentanter i media. En komparativ analys av mediabild och självrepresentation. Statsvetenskaplig tidskrift, 121(2), 207-240. 
Robertson, Alexa. (2017). Narrative Analysis. I Kristina Boréus \& Göran Bergström (Red.), Analyzing Text and Discourse. Eight Appraoches for the Social Sciences (s. 122145). Sage.

Riessman, Catherine Kohler. (2005). Narrative Analysis. In Narrative, Memory \& Everyday Life, 1-7. University of Huddersfield: Huddersfield. Hämtad från: http://eprints.hud.ac.uk/id/eprint/4920/

Røvik, Kjell Arne, \& Pettersen, Hilde M. (2014). Masterideer. I Kjell Arne Røvik, Tor Vidar Eilertsen, \& Eli Moksnes Furu (Red.), Reformideer i norsk skole. Spredning, oversettelse og implementering (s. 53-86). Cappelen Damm Akademisk.

Sahlberg, Pasi (2016). The global educational reform movement and its impact on schooling. In Karen Mundy, Andy Green, Bob Lingard, \& Antoni Verger (Red.), The handbook of global education policy (s. 128-144). John Wiley \& Sons, Ltd.

Shaw Sara E., \& Bailey Julia (2009). Discourse analysis: what is it and why is it relevant to family practice? Family Practice; 26(5), 413-419. doi:

101093/fampra/cmp038

Skolverket (2014). Riktlinjer för nationell skolutveckling Så gör vi skillnad. Skolverket.

Skolverket (2016). Redovisning av genomförandeplan för uppdrag om samverkan för bästa skola samt redovisning av hur arbetet genomförts hittills. (Dnr 2015:778). Skolverket. Hämtad från: https://www.skolverket.se/getFile?file=3611

Skolverket (2019a). Redovisning av uppdrag om Samverkan för bästa skola. (Dnr 7.2.12015:778). Skolverket. Hämtad från: https://www.skolverket.se/publikationsserier/regeringsuppdrag/2019/uppdragom-samverkan-for-basta-skola

Skolverket (2019b). Samverkan för bästa skola. Hämtad 11 december 2019 frän https://www.skolverket.se/skolutveckling/leda-och-organiseraskolan/samverkan-for-basta-skola

SOU 2014:5. Staten fär inte abdikera - om kommunaliseringen av den svenska skolan. Fritzes Offentliga Publikationer.

Springer, Simon (2012). Neoliberalism as discourse: between Foucauldian political economy and Marxian poststructuralism. Critical Discourse Studies, 9(2), 133-147. DOI:10.1080/17405904.2012.656375

Sullivan, Helen, \& Skelcher, Chris (2002). Working Across Boundaries. Collaboration in Public Services. Palgrave MacMillan.

Sülau, Veronica (2019). Vad händer i lärares kollegiala samtalspraktik? En studie av mötet mellan en nationell kompetensutvecklingsinsats och en lokal fortbildningspraktik. (Doktorsavhandling, Gothenburg Studies In Educational Sciences 437). Acta Universitatis Gothoburgensis. Tillgänglig: http://hdl.handle.net/2077/60280

Säfström, Carl Anders (2005). The European knowledge society and the diminishing state control of education: the case of Sweden. Journal of Education Policy, 20(5), 583-593. https://doi.org/10.1080/02680930500222386 
Utbildningsdepartementet (2015). Uppdrag om samverkan för bästa skola.

(U2015/3357/S). Tillgänglig:

https://www.regeringen.se/49cb50/contentassets/583f248e9baa4d9a80f73c30e5f

53c30/uppdrag-om-samverkan-for-basta-skola.pdf

Vallberg Roth, Ann-Christine (2014). Bedömning i förskolors dokumentation fenomen, begrepp och reglering. Pedagogisk Forskning i Sverige 19(4-5), 403-437.

Watson, Cate, \& Drew, Valerie (2017). Enacting educational partnership: collective identity, decision-making (and the importance of the muffin chat). School Leadership \& Management 37(1-2), 3-18. DOI: 10.1080/13632434.2016.1209181

Winther Jørgensen, Marianne \& Philips, Louise (2000). Diskursanalys som teori och metod. Studentlitteratur.

Ärlestig, Helene, \& Johansson, Olof (2020). Sweden: High Policy Ambitions with Soft Accountability. I Helene Ärlestig \& Olof Johansson (Red.), Educational Authorities and the Schools. Organisation and Impact in 20 States (s. 93-108). Springer. 